\title{
Bacteriological Analysis of Water Quality in a Recreational Park Pond in Rivers State, Nigeria
}

\author{
ABU, GO; *OTOKUNEFOR, K; DAPPA, CD \\ Department of Microbiology, Faculty of Science, University of Port Harcourt, PMB 5323, Choba, Port Harcourt, Rivers State. \\ *Corresponding Author Email: kome.otokunefor@uniport.edu.ng
}

\begin{abstract}
Bacteriological analysis of a Recreational Park Pond in Port Harcourt was investigated to evaluate the water quality of the pond for recreational purposes. Samples collected from the pond were evaluated for physiochemical and bacteriological study. $\mathrm{pH}$ showed a slight alkaline range of 6.66-6.94 in sample A and D with a temperature range of $28.6-29^{\circ} \mathrm{C}$. Samples evaluated for turbidity and salinity showed values of $0.309-0.784 \mathrm{NTU}$ and $0.10 \mathrm{ppt}$ to $0.32 \mathrm{ppt}$ respectively. Similar bacteriological load ranging from $6.9 \times 10^{5} \mathrm{cfu} / \mathrm{ml}-2.1 \times 10^{6} \mathrm{cfu} / \mathrm{ml}$ was observed, with coliform counts ranging from $3.4 \times 10^{5}-1.3 \times 10^{6} \mathrm{cfu} / \mathrm{ml}$. Thirteen different bacterial genera were identified in total (Escherichia coli, Salmonella spp., Proteus spp., Citrobacter spp., Klebsiella spp, Bacillus spp., Serratia spp., Pseudomonas spp., Vibrio spp., Enterobacter spp., Staphylococcus aureus, Streptococcus spp., and Staphylococcus spp). Escherichia coli was the most commonly occurring group (14.7\%) and Staphylococcus sp the least occurring (2.9\%). Varying levels of resistance was noted against the 14 antibiotics tested, with the highest resistance noted against pefloxacin $(55.9 \%)$ while the lowest resistance was against erythromycin (2.9\%). Majority of isolates (67.7\%) however had MAR index values less than 0.21 , indicative of a source related to low antibiotic use. Despite the association of potentially pathogenic bacteria with this water body, the low level of drug resistance associated with these organisms as well as the MAR index values, could point at these being environmental rather than human strains. Further molecular studies would be advised to confirm this.
\end{abstract}

\section{DOI: https://dx.doi.org/10.4314/jasem.v24i1.4}

Copyright: Copyright (C) $2020 \mathrm{Abu}$ et al. This is an open access article distributed under the Creative Commons Attribution License (CCL), which permits unrestricted use, distribution, and reproduction in any medium, provided the original work is properly cited.

Dates: Received: 30 November 2019; Revised: 20 December 2019; Accepted: 23 December 2019

Keywords: Bacteriological analysis, recreational water, antibiotic resistance, pefloxacin

A pond is referred to as a landlocked small mass of freshwater formed naturally or artificially and can be used for various purposes (Douglas and Isor, 2015). Dug ponds such as the Pleasure Park Pond are created by removing soil and allowing water to fill in the dugout area, with water supply from ground water seepage or natural springs. The soils of ponds are usually made up of different porous layers that allow water to ooze freely through the bottom of the pond (Abu and Wondikom, 2018). Pond waters may be polluted due to discharge of effluents from various industries, domestic waste, land and agricultural drainage this causes a deleterious change in the water quality. The purpose served by pond determines how much focus is placed on its water quality. The primary use of pond is a necessary factor in measuring the water quality parameters. For example, parameters used to assess a pond that supplies drinking water are different from those used to measure a pond for recreational or fishing activities. The health risks associated with water contact activities like boating include being infected with harmful disease-causing bacteria, which may be detrimental to health (Kishinhi et al., 2006). Water is one of the vehicles involved in the reproduction and transfer of human-associated bacteria (Faria et al., 2009). Safe water is a fundamental human right and if contaminated with pathogenic bacteria, it might lead to a high negative public health implication (Fawell et al., 2003). Pond water composition may be murky if it has a high amount of suspended particles and organisms. Its bottom is usually sediments of sand, decaying matter and microorganisms. Pond ecosystems are often teeming with rich vegetation and a diverse organismal life. Many are every day organisms that are found anywhere. Ponds may however be contaminated by direct excretion (vomit, faeces, urine, saliva) from fishes or users (Hoseinzadeh et al., 2013) and by external sources from sewage, storm water, and agricultural runoff or faeces from birds (El-Salam et al., 2012). Common microorganisms associated with ponds include Salmonella sp., Vibrio sp., Pseudomonas aeroginosa, Bacillus sp., Staphylococcus sp., Klebsiella sp., and Citrobacter sp.

Bacteriological monitoring of ponds is based on natural knowledge of the sanitary condition of the water supply, which is based on the detection of coliform bacteria and the specific indicator of human faecal contamination (Idakwo and Abu, 2004). The 
indicator bacteria used to monitor water quality are generally coliforms. They make up $10 \%$ of the intestine microorganisms of human and animals. Water is considered portable for human consumption or recreational activities when foreign enteric bacteria are not detected in a specific volume $(100 \mathrm{ml})$ of water. The use of intestinal organisms as indicators of faecal contamination is a universally acceptable process for monitoring and assessing the microbiological safety of water supply before distribution. Two of the most widely accepted bacterial indicator organisms are Escherichia coli and Streptococcus due to their faecal linkages, and ease in laboratory analysis (Harwood et al., 2004). Pond water serves as a natural habitat of both pathogenic bacterial strains with potentially important roles in disease process and multidrug resistant organisms. Similarly increase of faecal pollution in source water is also a problem in developing as well as developed countries (Bezuidenhout et al., 2002). The World Health Organization (WHO) estimates that 3.4 million people, mostly children die every year from waterrelated diseases (Wilkes et al., 2009). These resistant pathogens may be transmitted to humans, farm animals and birds causing infections that cannot be treated by conventional antibiotics. This study was carried out to evaluate the bacteriological profile of the pleasure park pond, as well as determine drug resistance of the associated bacteria.

\section{MATERIALS AND METHODS}

Sample collection: Samples were collected from a recreational park pond in Rivers State, Nigeria (Fig 1).

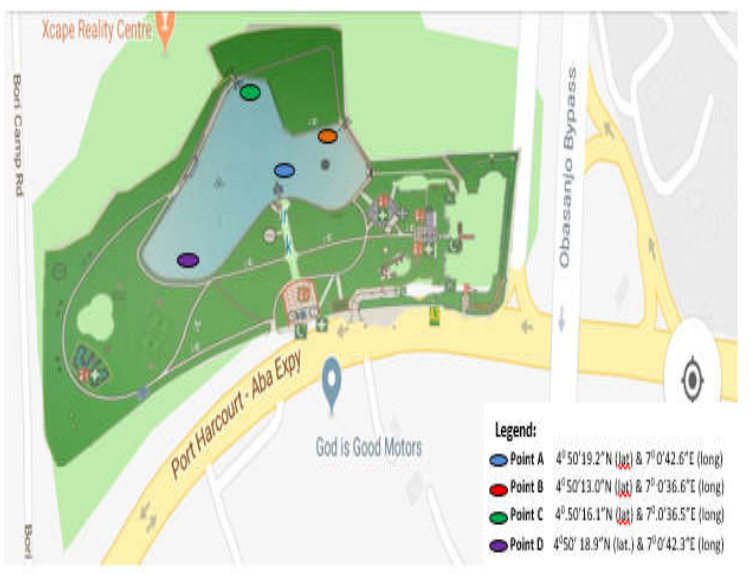

Fig 1: Map showing Pleasure Park Pond sampling points and its geographical coordinate (SOURCE; Google.com)

Water samples were collected from the four cardinal points of the pond. Two samples were collected from each point, at a depth of about $(1-2 \mathrm{~cm})$ for surface and $(10-12 \mathrm{~cm})$ for subsurface. Bacteriological and physicochemical analyses of these samples were carried out at the University of Port Harcourt microbiology laboratory within 8 hours of collection. All sampling points were geo-referenced using a handheld GPS receiver unit (Megellan GPS 315) to generate geographical coordinates (latitude and longitude) at the pond.

Physicochemical Analysis: The pH, temperature and turbidity were measured using standard procedures (Njoku et. al., 2015). The $\mathrm{pH}$ of each water sample was measured using a Phillips model of PW 9418 pH meter while temperature was measured using a mercury thermometer. Turbidity was measured by spectrophotometry at a wavelength of $555 \mathrm{~nm}$ and conductance measured at room temperature using the Hach conductivity meter, Model CO150.

Enumeration and Isolation of Potential Bacterial Pathogens: Enumeration of total aerobic heterotrophic bacterial (THB) population was done following a tenfold serial dilution of the pond water using physiological saline up to $10^{-5}$ by plating out $0.1 \mathrm{ml}$ aliquot of each dilution onto duplicate set of nutrient agar using the spread plate method.

Aliquots from diluted water samples were also spread plated on mannitol salt agar (MSA) and MacConkey agar (MCA) plates in order to assess for the presence of Staphylococcus species and lactose fermenting enteric bacteria respectively. The inoculated plates were incubated for 24 hours at $37^{\circ} \mathrm{C}$.

Isolation of Salmonella and Shigella: This was done using the Salmonella/Shigella agar which was prepared according to manufacturer's instruction, The water samples was also enriched in selenite $F$ broth and then $0.1 \mathrm{ml}$ aliquot of the sample was spread plated on the surface of SSA plates which were then incubated for 24 at $37^{\circ} \mathrm{C}$.

Characterization and Identification of Bacterial Isolates: Pure forms of the bacterial isolates were characterized and identified based on their motility, microscopic morphology, colonial morphology and biochemical characterization using standard methods (Krieg and Holt, 1994, Cheesbrough, 2002).

Antibiotic Susceptibility Studies: Antibiotic susceptibility of the isolates was determined using the Kirby-Bauer disc diffusion method on Mueller-Hinton agar (Bauer et al., 1966). A total of 14 antibiotics corresponding to drugs most commonly used in the treatment of human and animal infections caused by Gram negative and Gram positive bacteria were employed in this study. The antibiotics include; Gentamicin, Augmentin, Ciprofloxacin, 
Streptomycin, Penicillin, Pefloxacin, Cotrimoxazole, Tarvid, Erythromycin, Cephalexin, Ampiclox, Amoxicillin, Sparfoxacin, Chloramphenicol. Overnight cultures of the bacterial isolates were inoculated into peptone water and incubated at $37^{\circ} \mathrm{C}$ for 4hours. The density of the bacterial culture required for the assay was adjusted to $0.5 \mathrm{McF}$ arland standards. The Mueller-Hinton agar plates were uniformly inoculated using a swab stick. The plates were allowed to dry for $10 \mathrm{~min}$, antibiotic impregnated paper discs aseptically placed on the surface of the Mueller-Hinton agar medium and plates incubated at $37^{\circ} \mathrm{C}$ for 24 hours. A clear zone of inhibited growth around each antibiotic impregnated disc was measured. The degree of susceptibility of the test organism to each antibiotic was determined and interpreted as either sensitive (S), intermediate susceptible (I), or resistant (R) in accordance with the British society for antimicrobial chemotherapy (BSAC) (Andrew, 2007).

Additionally, multiple antibiotic resistance (MAR) index and multidrug resistance (MDR) were determined as previously described (Cookey and Otokunefor, 2016).

\section{RESULTS AND DISCUSSION}

\section{Physicochemical Characteristics.}

The

physicochemical parameters of the samples showed similarities at all the points of the pond sampled (Figure 2). Samples were noted to have a slightly high $\mathrm{pH}$ ranging from $6.66-6.94$, turbidity values ranged from $0.309-0.784$ NTU while salinity of the pond water ranged from $0.10 \mathrm{ppt}-0.32 \mathrm{ppt}$.

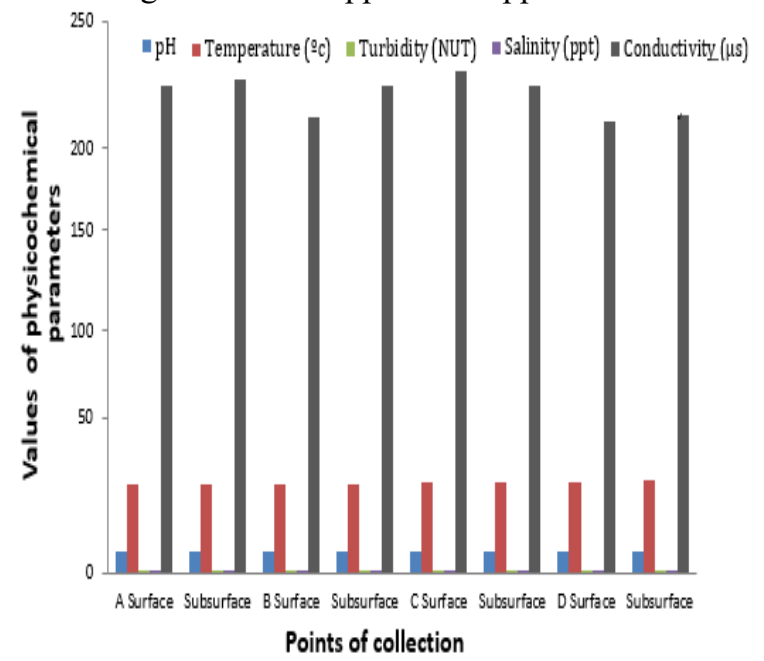

Fig 2: Physicochemical parameters of water samples from various points of the Pleasure park pond

Bacteriological Analysis: All samples had similar levels of the various groups of bacteria (Table 1) with counts ranging from $4.1 \times 10^{5}-2.9 \times 10^{6} \mathrm{CFU} / \mathrm{ml}$. Bacterial levels at both surface and subsurface levels were very similar with no location showing a greater than 1.5 CFU/ml difference. After culturing, 34 different isolates were obtained from the pond samples. A total of thirteen bacterial genera were identified from the 34 isolates (Figure 3). Nine of these were Gram-negative bacteria and four, Gram-positive. Escherichia coli was the most commonly occurring group of bacteria $(14.7 \%)$ and Staphylococcus sp the least occurring $(2.9 \%)$.

Table 1: Total Heterotrophic Bacterial (THB) count, Staphylococcus count, Vibrio count, and Faecal Coliform Bacterial (FCB) counts of water sample from the Pleasure park pond

\begin{tabular}{lllll}
\hline $\begin{array}{l}\text { Sample } \\
\text { Source }\end{array}$ & $\begin{array}{l}\text { THBC } \\
\text { (CFU/mI) }\end{array}$ & $\begin{array}{l}\text { Staphylococcus } \\
\text { Count (CFU/mI) }\end{array}$ & $\begin{array}{l}\text { Vibrio Count } \\
\text { (CFU/mI) }\end{array}$ & (CFU/ml) \\
\hline $\begin{array}{l}\text { Point A } \\
\text { Surface }\end{array}$ & $1.7 \times 10^{6}$ & $1.2 \times 10^{6}$ & $8.1 \times 10^{5}$ & $4.1 \times 10^{5}$ \\
$\begin{array}{l}\text { Sub surface } \\
\text { Point B }\end{array}$ & $1.2 \times 10^{6}$ & $5.4 \times 10^{5}$ & $6.6 \times 10^{6}$ & $6.4 \times 10^{5}$ \\
Surface & $1.2 \times 10^{6}$ & $5.4 \times 10^{5}$ & $1.6 \times 10^{6}$ & $3.4 \times 10^{5}$ \\
Sub surface & $1.2 \times 10^{6}$ & $5.6 \times 10^{5}$ & $2.9 \times 10^{6}$ & $4.6 \times 10^{5}$ \\
Point C & & & & \\
Surface & $6.9 \times 10^{5}$ & $8.6 \times 10^{5}$ & $2.4 \times 10^{6}$ & $4.6 \times 10^{5}$ \\
Sub surface & $7.9 \times 10^{5}$ & $5.5 \times 10^{5}$ & $8.8 \times 10^{5}$ & $6.6 \times 10^{5}$ \\
Point D & & & & \\
Surface & $7.7 \times 10^{5}$ & $5.4 \times 10^{5}$ & $1.0 \times 10^{6}$ & $5.3 \times 10^{5}$ \\
Sub surface & $8.2 \times 10^{5}$ & $5.1 \times 10^{5}$ & $1.3 \times 10^{6}$ & $1.3 \times 10^{6}$ \\
\hline
\end{tabular}

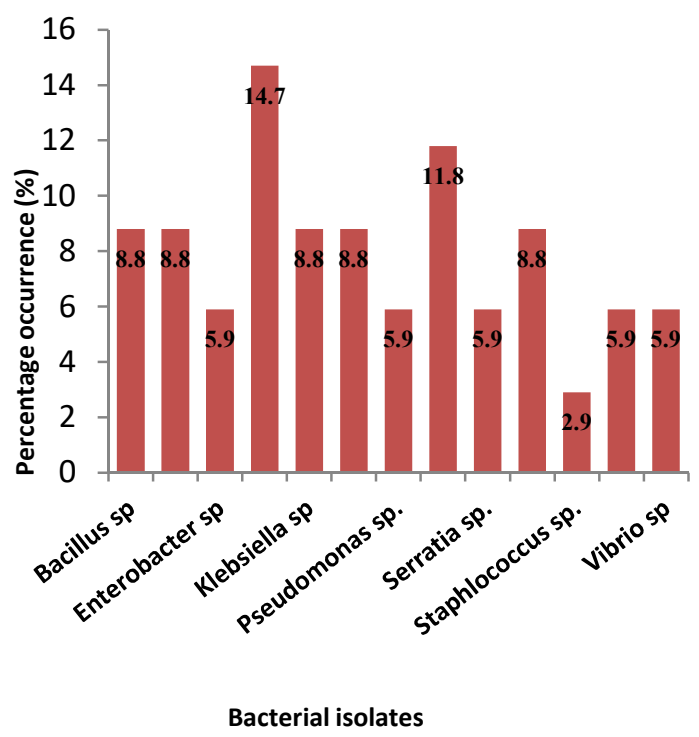

Fig 3: Distribution of potential pathogens isolated from Port Harcourt Pleasure Park Pond.

Antibiotic Susceptibility: Following susceptibility testing, results showed varying levels of resistance against the 14 antibiotics tested (Figure 4). The highest level of resistance was observed against pefloxacin $(55.9 \%)$ and the lowest against erythromycin (5.9\%). Generally, a higher level of resistance was noted in 
isolates obtained from Point D (8/14, 57.1\%), than other locations (Figure 5), while Point A had a lower level of resistance $(7 / 14,50 \%)$ in most cases

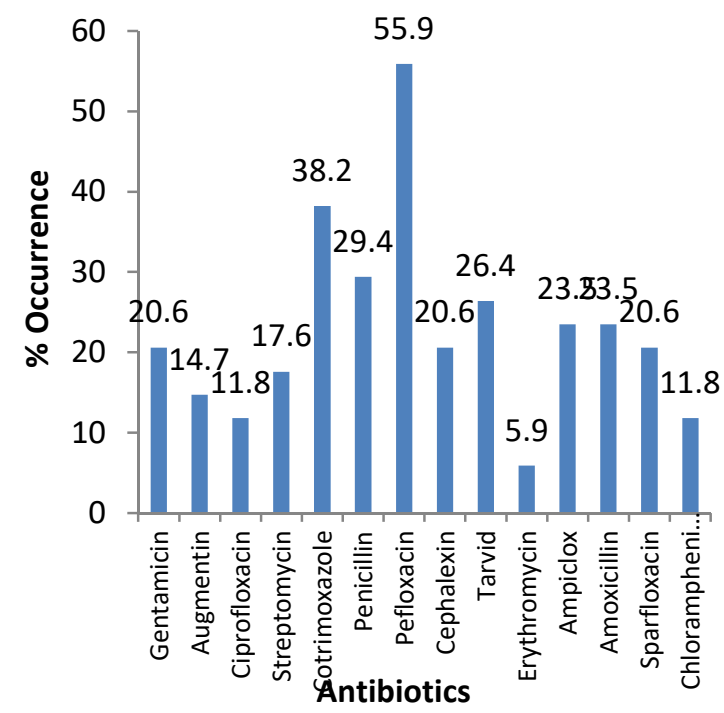

Figure 4: Antibiotic Susceptibility of Isolates

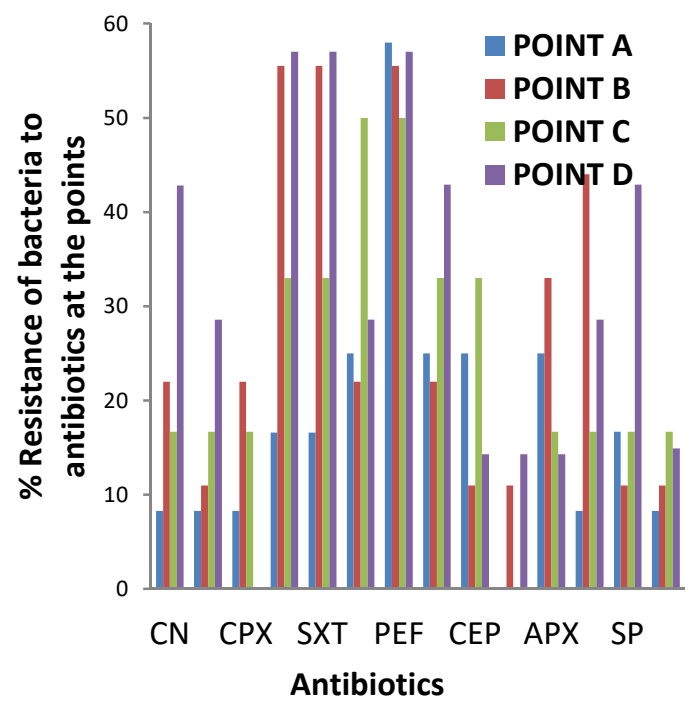

Fig 5: Variation in antibiotic resistance among bacteria isolated from the different test locations.

Results of this study showed that majority of the isolates (67.7\%) had MAR index values less than 0.21 , indicative of a source related to low antibiotic use (Figure 6). No isolate in this study was associated with the extreme MAR index values $(>0.80)$. An assessment of MDR (resistance to 3 or more antibiotic classes) showed a $38.2 \%$ rate of multidrug resistance.

Recreational waters could serve as a source of infection following direct contact or via aerosols. Knowledge of physicochemical and bacteriological characteristics of such water bodies is essential due to possible public health implications. With respect to physicochemical analysis, $\mathrm{pH}$ analysis of this study shows values slightly below the WHO standard for $\mathrm{pH}$ of pond water (WHO, 2006).

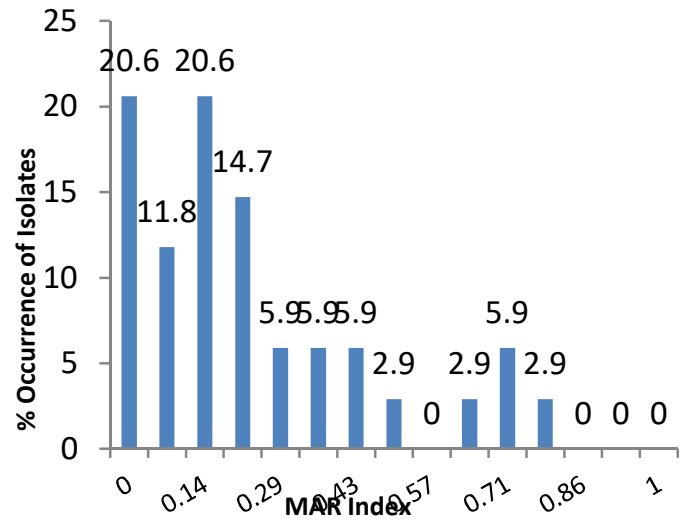

Fig 6: MAR Index distribution of isolates

This could be as a result of dissolution ions from the soil into the pond water. Being an earthen pond it has some level of suspended solid which is due to the soil sediments, disturbances during runoff. Salinity which has been described as among the most important factors due to its effects on the vitality of microorganisms is dependent on levels of evaporation (Torimiro et al., 2014). The salinity values in this study were typical of a freshwater body falling below 0.5 . Temperature and conductivity values of this study fell within the WHO standard. Bacterial load has previously been reported to vary depending on water layer (Qin et al., 2016). In this study, similar levels of bacterial load were noted at both surface and subsurface layers. This is most likely a reflection on the proximity to the surface of both sampling points. Studies which reported a difference in bacterial load compared highly variable water layers which reflected variations in both dissolved oxygen and organic content. It was found that Gram negative bacteria were the predominant genera among the pond organisms. This phenomenon has previously been reported by studies exploring the diversity of microflora in various types of ponds (Molokwu and Okpokwasili, 2002, Khunthongpan et al., 2013, Njoku et al., 2015, Douglas and Isor 2015). One major variation between this present study and previous studies is that most other studies failed to look at ponds simply for recreational purposes but rather focused on aquaculture or domestic ponds. This is probably due to the fact that recreational ponds are not widespread in this locality. E. coli specifically was the predominant group of bacteria isolated in this study. In general, most of the bacterial genera isolated have previously been described in association with ponds. This source of microorganisms may be a reflection of water sources fed into the pond as it uses a topping system where more water is added in order to maintain 
specific volume of water level through runoff from different sources. The isolates with high frequency of occurrence are potential important human pathogens associated with a variety of infectious diseases such as gastroenteritis, typhoid fever, dysentery, cholera, urinary tract infection (Uzoigwe and Agwa, 2012). The level of faecal coliform load observed in this research study proposes that the pleasure park pond is unfit for non-boating purposes such as domestic, aquaculture and recreational purposes like swimming. This may be due to pollution from the water source in the area caused by human activities (such as human waste disposal, defecation, and fishing). Climate change and other heightened ecological disturbances such as flooding are all possible sources of contamination (Mbah et al., 2016). These multiple sources of contamination are compounded by limited environmental awareness, which is prominent in rural areas (Dick et al., 2015), but also in urban areas such as the Pleasure Park Pond in Port Harcourt.

While the current information on drug resistant bacteria in recreational waters specifically is limited (Fang et al., 2018), several studies have assessed this situation in natural lakes which might be used for human activities. In contrast to our study which reported low rates of resistance to most antibiotics apart from pefloxacin, some other studies reported rates of resistance greater than 50\% (Yin et al., 2013, Akanbi et al., 2017, Turetken et al., 2019). Yin and colleagues reported high rates against penicillin and streptomycin antibiotics specifically, while Akanbi and colleagues reported generally high levels of resistance against all drug classes tested. A 2007 study assaying for resistance genes, reported even lower levels of drug resistance than this present study (Hamelin et al., 2007). As anthropogenic activities are known to influence the levels of bacterial resistance (Lobova et al., 2011, Pashang et al., 2019), the low levels of resistance are most likely as a result of low levels of anthropogenic activities in the source of the runoffs. In contrast to susceptibility patterns to other antibiotics, a high rate of resistance $(55.9 \%)$ was noted against perfloxacin. This drug is used in veterinary medicine particularly in poultry farming and similar values have been described in organisms isolated from poultry environment (Moutafchieva and Yarkov 2006, Hemen et al., 2012, Musa et al., 2017, Oloso et al., 2019).

Conclusion: Despite the association of potentially pathogenic bacteria with this water body, the low level of drug resistance associated with these organisms as well as the MAR index values, could point at these being environmental rather than human strains.
Further molecular studies would be advised to confirm this.

\section{REFERENCES}

Abu, GO; Wondikom, AC (2018) Isolation, Characterization and Antibiotic Resistance Profile Studies of Bacteria from an Excavated Pond in Port Harcourt Metropolis, Nigeria. Journal of Applied Science Environmental Management. 22 (8) 1177 - 1184.

Akanbi, OE; Njom, HA; Fri, J; Otigbu, AC; Clarke, AM (2017). Antimicrobial Susceptibility of Staphylococcus aureus Isolated from Recreational Waters and Beach Sand in Eastern Cape Province of South Africa. International Journal of Environmental Research and Public Health. 14(9): 1001.

Andrews, JM (2007). BSAC Standardized Disc Susceptibility Testing Method (Version 6). Journal of Antimicrobial Chemotherapy. 60(1): $20-41$.

Bauer, AW; Kirby, WMM; Strerris, JC; Turk, M (1966). Antibiotic Susceptibility Testing by a Standard Single Disk Method. American Journal of Clinical Pathology.45: 493 - 496

Bezuidenhout, CC; Mthembu, C; Puckree, T; Lin, J (2002). Microbiological Evaluation of the Mhlathuze River, KwaZulu-Natal (RSA). Water SA. 28(3): $281-286$

Cheesbrough, M (2002). District Laboratory Practice in Tropical Countries, 2 Microbiology. Cambridge University Press.

Cookey, TI; Otokunefor, K (2016). Poultry Environment as a Reservoir of Antimicrobial Resistant Bacteria - A Nigerian Story. British Microbiology Research Journal. 17(1): 1 - 11 .

Dick, AA; Abu, GO; Ibe, SN (2015). Antibiotic Sensitivity and Plasmid Profiles of Bacteria Isolated from Water Sources in Oproama Community in the Niger Delta. Biokemistri. An International Journal of the Nigerian Society for Experimental Biology. 27 (1) $14-21$.

Douglas, SI; Isor, FN (2015). Bacteriological investigation of pond water quality from Ogoniland, Nigeria. IOSR Journal of Environmental Science, Toxicology and Food Technology. 9(2): $36-41$. 
El-Salam, MM (2012). Assessment of Water Quality of Some Swimming Pools: A Case Study in Alexandria. Environmental Monitoring Assessment. 184(112): 7395 - 7406.

Fang, T; Wang, H; Cui, Q; Rogers, M; Dong, P (2018). Diversity of Potential Antibiotic-Resistant Bacterial Pathogens and the Effect of Suspended Particles on the Spread of Antibiotic Resistance in Urban Recreational Water. Water Research. 145: $541-551$.

Faria, C; Vaz-Moreira, I; Serapicos, E; Nunes, O; Manaia, C (2009). Antibiotic Resistance in Coagulase Negative Staphylococcus Isolated from Waste Water and Drinking Water. Science of the Total Environment. 407(12): 3876 - 3882.

Fawell, J; Nieuwenhuijsen, M (2003). Contaminants in Drinking Water Environmental Pollution and Health. British Medical Bulletin. 68: 199 - 208.

Hamelin, K; Bruant, G; El-Shaarawi, A; Hill, S; Edge, TA; Fairbrother, J; Harel, J; Maynard, C; Masson, L; Brousseau, R (2007). Occurrence of Virulence and Antimicrobial Resistance Genes in Escherichia coli Isolates from Different Aquatic Ecosystems within the St. Clair River and Detroit River areas. Applied and Environmental Microbiology. 73(2): 477 - 484.

Harwood, VJ; Gandhi, JP; Wright, AC (2004). Methods for Isolation and Confirmation of Vibrio vulnificus from Oysters and Environmental Sources: A Review. Journal of Microbiological Methods. 59: $301-316$.

Hemen, JT; Johnson, JT; Ambo, EE; Ekam, VS; Odey, MO; Fila, WA (2012). Multi-antibiotic Resistance of some Gram Negative Bacterial Isolates from Poultry Litters of Selected Farms in Benue State. International Journal of Science and Technology. 2(8): 543 - 547.

Hoseinzadeh, E; Mohammady, F; Shokouhi, R (2003). Evaluation of Biological and Physicochemical Quality Public Swimming Pools, Hamadan (Iran). International Journal of Environmental Health. 2(11): 21 .

Idakwo, PY; Abu, GO (2004). Distribution and Statistical Analysis of Bacteria in Lake Alau in the Arid Northern Nigeria. Journal of Applied Sciences and Environmental Management. 8(1): 5 -9 .
Khunthongpan, S; Sumpavapol, P; Tanasupawat, S; Benjakul, S; H-Kittikun, A (2013). Providencia thailandensis sp. Isolated from Seafood Processing Wastewater. The Journal of General Application of Microbiology. 59: 185 - 190.

Kishinhi, S; Tchounwou, PB; Farah, IO; Chigbu, P (2006). Recreational water quality control in Mississippi, USA: Bacteriological assessment in the Pearl River and Ross Barnett reservoir. Reviews on Environmental Health. 21(4): 295 307.

Krieg, NR; Holt, JG (1994). Bergey's Manual of Systematic Bacteriology. William and Wilkins, Baltimore Ltd.

Lobova, TI; Feil, EJ; Popova, LY (2011). Multiple Antibiotic Resistance of Heterotrophic Bacteria Isolated from Siberian Lakes Subjected to Differing Degrees of Anthropogenic Impact. Microbial Drug Resistance. 17(4): 583 - 591.

Mbah, EI; Abu, GO; Ibe, SN (2016). MetagenomesBased Investigation of the Impact of Natural Runoffs and Anthropogenesis on a Freshwater Ecosystem at Points of Use in Niger Delta, Nigeria. International Journal of Innovative Research Development (IJIRD). 1(1): 15 - 22.

Molokwu, CN; Okpokwasili, GC (2002). Microbial Flora of Clarias gariepinus in the Early Stages of Development. Tropical Freshwater Biology. 11: $91-100$.

Moutafchieva, R; Yarkov, D (2006). Pharmacokinetics of Pefloxacin in Birds. Trakia Journal of Sciences. 3: 28 - 33.

Musa, JA; Dauda, KI; Lawani, FA; Diyo, D; Meshack, MM; Jauro, S (2017). Prevalence and Antibiotic Sensitivity Pattern of Salmonella isolates from Milk Products and Water Reservoirs in Maiduguri, North-Eastern Nigeria. IOSR Journal of Agriculture and Veterinary Science (IOSRJAVS). 10(2). 2319 - 2380.

Njoku, OE; Agwa, OK; Ibiene, AA (2015). An investigation of the Microbiological and Physicochemical profile of some fish pond Water within the Niger Delta region of Nigeria. African Journal of Food Science. 9(3): 155 - 162.

Njoku, OE; Agwa, OK; Ibiene, AA (2015). An Investigation of the Microbiological and Physicochemical Profile of some Fish Ponds Water within Niger Delta of Nigeria. African Journal of Food Science. 9(3): 155 - 162. 
Oloso, NO; Adeyemo, IA; van Heerden, H; Fasanmi, OG; Fasina, FO (2019). Antimicrobial Drug Administration and Antimicrobial Resistance of Salmonella Isolates Originating from the Broiler Production Value Chain in Nigeria. Antibiotics. 8(2), 75.

Pashang, R; Yusuf, F; Zhao, S; Deljoomanesh, S; Gilbride, KA (2018). Widespread Detection of Antibiotic-Resistant Bacteria from Natural Aquatic Environments in Southern Ontario. Canadian Journal of Microbiology. 65(4): 322 31.

Qin, Y; Hou, J; Deng, M; Liu, Q; Wu, C; Ji, Y; He, X (2016). Bacterial Abundance and Diversity in Pond Water Supplied with Different Feeds. Scientific Reports. 6: 35232.

Torimiro, N; Bebe, PT; Ogundipe, FE; Esan, DM; Aduwo, AI (2014). The Bacteriology and Physico-chemical Analysis of Freshwater Fish Ponds. International Research Journal of Microbiology. 5(3): $28-32$.

Türetken, PS; Altuğ, G; Çardak, M; Güneş, K (2019). Bacteriological Quality, Heavy Metal and Antibiotic Resistance in Sapanca Lake, Turkey.
Environmental Monitoring and Assessment. 191(7): 469.

Uzoigwe, CI; Agwa, OK (2012). Microbiological Quality of Water Collected from Boreholes Sited near Refuse Dumpsites in Port Harcourt, Nigeria. African Journal Biotechnology. 11(13): 3135 3139.

Wilkes, G; Edge, T; Gannon, V; Jokinen. C; Lyautey, E; Medeiros, D; Neumann, N; Ruecker, N; Topp, E; Lapen, DR (2009). Seasonal Relationships among Indicator Bacteria, Pathogenic Bacteria, Cryptosporidium oocysts, Giardia cysts, and Hydrological Indices for Surface Waters within an Agricultural Landscape. Water Resources. 43: $2209-2223$.

World Health Organization (2006). Guidelines for safe recreational water environments: Swimming pools and similar environments.

Yin, Q, Yue, D, Peng, Y, Liu, Y, Xiao, L (2013). Occurrence and Distribution of AntibioticResistant Bacteria and Transfer of Resistance Genes in Lake Taihu. Microbes and Environments. 28(4): $479-486$. 